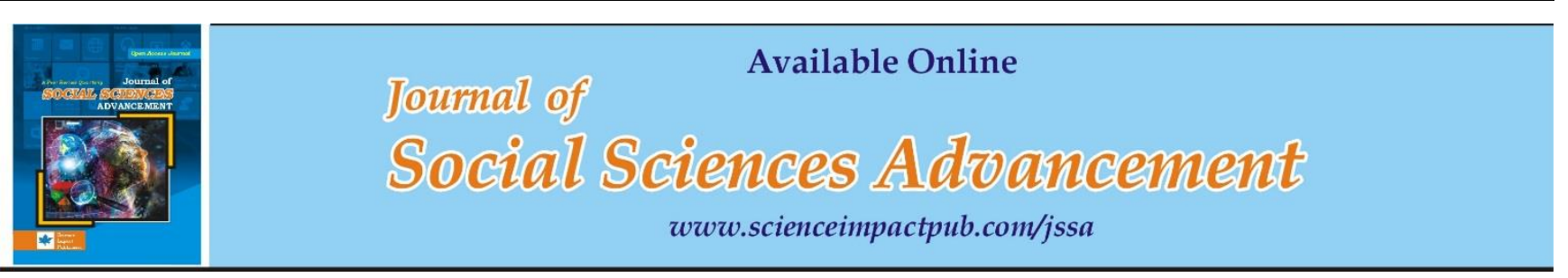

\title{
Customers' Perception towards CRM Practices in reference to Organized Retail in India
}

\author{
Sulabh Agarwal ${ }^{*}$ and Shekhar Srivastava ${ }^{2}$ \\ ${ }^{1}$ Ajay Kumar Garg Institute of Management, Ghaziabad, India \\ 2Babu Banarasi Das University, Lucknow, India
}

\begin{abstract}
Retailing being one of the fastest growing sectors is facing tremendous competition from domestic as well as foreign players. Customer retention is an area of serious concern for online as well as offline retailers in the Indian economy, driving players in the Indian business scenario to bring radical change in their CRM practices which affects their customers' perception. Retailers are highly concerned in identifying the key drivers of service execution that model customer shopping satisfaction and enhance loyalty. Customer satisfaction \& loyalty is an outcome of sound customer relationship management practices. Thus, to ensure the prolong survival in the highly aggressive retail business environment customer centric approach is hour's need. This paper critically analyses Customer's perception towards CRM practices with reference to organized retail in India. Major parameters such as reliability, product attributes, customer service, convenience and ambience are identified to evaluate the customer perception towards CRM practices. The relevance of each parameter is analyzed with special reference to both the formats of organized retailing i.e., online \& offline. For in-depth analysis of each parameter in both the formats of retail, they are further divided into sub-parameters. A survey is conducted for collecting data about customers' perception towards these parameters. A statistical tool two-way ANOVA is used to analyze the variation in customer perception between online and offline retail. Based on analysis and major findings of research a conceptual model is also being proposed to get a pictorial view of how these parameters are affecting customers' perception towards online and offline retail.
\end{abstract}

\begin{tabular}{l}
\hline Keywords: Customer perception; CRM; Organized retail; Parameters; Perception model \\
\hline *Corresponding Author: Sulabh Agarwal, Email: sulabh.agarwal1985@gmail.com \\
(c) The Author(s) 2021.
\end{tabular}

\section{INTRODUCTION}

Customer Relationship Management is basically a philosophy and strategic process \& system which lay emphasis to identify and build loyalty with high valued customers. Also, as a comprehensive strategy and process of securing, holding, and associating with selective customers, it creates superior value for the company and the customer. Customer satisfaction is positively related with customer loyalty as a satisfied customer plays the role of a free publicity agent for the company and spread word of mouth for them. But organizations should work not only for creating a pleased customer but also, for building reliability and loyalty among customers for unmatched paybacks as the cost of creating a new customer is remarkably high as compared to that of retaining an existing one.

Luis Arditto, (2020) concluded that customer perception of the salespeople in terms of proficiency, faith, communication, and risk can drive the establishment of long-lasting ties, making customer portfolio management profitable in the long-term. Retail in India has paced industries with several players entering the retail market. Retailing in India is gradually inching its way to becoming the next boom industry. Dinesh K. Gauri, (2021) commented that many challenges faced by offline (physical store) and online (digital) retailers over development and expansion on strategies are pursued in order to address them. The highly demanding and knowledgeable consumers are compelling retailers to stock a huge product range, offer attractive discounts in an appealingly set up environment. The whole concept of shopping has changed in terms \& format and consumer buying preferences, bringing a revolution in retail industry.

\section{Organized retailing}

Anarock retail report, (2020) mentioned that Indian retail has arisen as one of the most dynamic and rapidly paced industries due to the access of several new competitors. Total consumption expenditure is projected to reach approx. US dollar 3,600 billion by 2020 from US dollar 1,824 billion in 2017 which accounts for about 10\% of the country's GDP and around 8\% of the total employment. India is the world's fifth-largest worldwide destination in the retail space.

As per Indian Retail Industry report, (2020) retail business touched US dollar 950 billion in 2018 at CAGR of thirteen percent and is projected to reach US dollar 1.1 trillion by 2020 . Online retail sales were forecasted to grow $31 \%$ year- 
over-year to reach US dollar 32.70 billion in 2018. Revenues from online retail is projected to touch US dollar 60 billion by 2020. Revenue of India's offline retailers which are brick and mortar retailers, is projected to increase by Rs. 10,000-12,000 crore (US dollar 1.39-2.77 billion) in FY20. The retail sector is expected to regain $~ 80 \%$ of preCovid revenue (totaling to US dollar 780 billion) by the end of 2020.

After a record fall of $19 \%$ in the January-March 2020 quarter, the FMCG industry shown signs of revival in JulySeptember 2020 with year-over-year growth of $1.6 \%$. The growth observed in the fast-moving consumer goods sector was also a reflection of positivity reflected in the overall macroeconomic scenario between opening of the economy and moderation of restrictions due to lockdown.

\section{LITERATURE REVIEW}

Monica Grosso, (2018) mentioned that there is an association between store loyalty and its prime driving factor, customer satisfaction. Satisfaction comes mainly from the store atmosphere and the perceived value of customers, which is persuaded by the retailers' product assortment judgments. Amazingly, promotions don't impact the perceived value, whereas the perceived value has only a minor and adverse impact on store loyalty.

Dinesh K. Gauri, (2021) reviewed the literature on retail formats comparisons, as per their attributes and competition among them; the role of customer behavior in selected format. They examine the challenges online and offline retailers face and discuss strategies each is following to deal with these challenges. They concluded that, newer digital-first \& physical-first retailers continue to come with different customer-focused formats and which they expect will slowly transform into integrated retailers, leaving space for new entrants to enter the market and keep rotating the wheel of retailing.

Kamrul Islam et al., (2015) stressed on the impact of customer relationship management on customer satisfaction and customer loyalty by empirical means and reviewing prior researches. The quality-of-service provided, optimistically affects customer satisfaction. When customers are satisfied, they tend to stay loyal. Employee training for CRM is essential, especially for sales personnel who deal with consumers. The training program of a CRM, orients sales personnel to acquire the requisite relationship building skills and an understanding of changing consumer needs. Therefore, management requires timely and precise data to build a strong customer relationship management program.

Manoj Kumar Jain, (2017) in an article "customer relationship management in Indian retail market" highlighted, how satisfied customers with a pleasing customer experience will always return. CRM helps to amplify customer satisfaction and offer an enjoyable shopping experience. Modern technologies are used to improvise the traditional thinking of treating "customer as god" to provide the finest services to customers. Here CRM plays a major role in meeting customer's expectations.

Parveen Banu M.A. et al., (2019) concluded that majority of customers are of the opinion that the main purpose of CRM is to gain customers' loyalty and retention. Proper facilities and a decent business plan is given more importance as a major success factor for CRM effectiveness.

Thenmozhi S. et al., (2018) have laid stress on that the retail stores should train their sales staff to enhance their communication skills so that a good relationship can be maintained with the customers. They believe CRM is more than business as it emphasizes personal bonding. Developing personal bonds like this can take the company to new heights of success. As the organizations are able to build this personal bonding, they can better understand the needs and serve their customer better. Implementing good CRM practices and tool should be a area of major concern for the retailers.

Gabriele Pizzi, (2020) state that technology fairness and satisfaction (self) act as precursors of consumer's technology acceptance, privacy perceptions \& perceived value; and they are responsible for the trust of consumers towards the retailer. Distributive fairness affects privacy perceptions, whereas the technology satisfaction (self) affects its acceptance.

Dubey et al., (2019) concluded that CRM technology capability is highly dependent on technology as compared to people and process. Research findings and some experts' opinion imply that the evolving collaborative-technologiesenabled CRM technology capability has transformed the customer relationship concept.

Yuen, E., Chan, S., (2010) investigates the influence of dimensions of service quality such as reliability, policy, physical aspects, personal interaction \& problem solving and dimensions of product quality such as customer perceived quality, aesthetics, features on customer loyalty. It was found that reliability, physical aspects \& problem solving are optimistically related to customer loyalty in retail shop whereas personal interaction have encouraging effect on customer loyalty towards staff. 
Hasan et al., (2018) selected some product attributes which discusses quality, fabric, brand name, style, size or fit, color etc. of the apparels. The broad attributes related to apparels in this paper comprised of color choice, design, ecofriendly, fitting, stitching, status symbol, price range, quality of fabric \& durability.

Dr. Ajay Kumar Sharma et al., (2017 inferenced that store ambience is related to some physical characteristics such as Lighting, music, smell/odor, temperature etc. These characteristics have a charismatic effect on the customers as they attract them to purchase products from the store. These factors of ambience have a psychological impact on the shoppers which helps them to relax and be cheerful; also motivates them to give more time to the store shopping. This increases the store's customer footfall and boosts the sales due to unplanned buying.

\section{Research gap}

Review of existing literature reveals that there is a lack of comparative study of customer perception parameters between online and offline mode of retailing in Indian context. As Indian market is very different from other markets of the world and its online retail space has huge growth possibilities and opportunities. Therefore, a new research has to be conducted in the view of key parameters and to analyze their impact separately over customer perception towards CRM practices in both the formats of retail.

\section{Research Objectives}

i. To analyze key parameters affecting customer perception in online Vs offline retailing.

ii. To propose a conceptual model interpreting customer perception.

\section{RESEARCH METHODOLOGY}

Considering the research nature, it is centered around primary and secondary data both. Where the primary data is collected by conducting a survey using a structured questionnaire based on certain parameters under study. The secondary data is collected from several journals (national as well as international), government reports, books \& articles, newspapers \& magazines, incorporating ample variety of literature as per the research area.

As per the research objectives, descriptive research design is used for thorough analysis of data collected. The secondary data available was widely used for academic research purposes only. Scope of this study is narrowed to Indian retail setup taking into consideration certain parameters. Pilot testing has been used for the standardization and validity of constructs. The survey approach is administered for research through a structured questionnaire.

Some research questions are addressed in this study:

i. What is the impact of selected key parameters on customer perception towards retailing?

ii. How these parameters affect customer perceptions differently in online and offline retail?

\section{Primary data}

An empirical study is conducted by administering a structured questionnaire to the consumers of organized retailing to understand the consumer perception towards CRM practices in organized retailing in India. The study was conducted in Lucknow city and 134 consumers participated in this research out of which 100 responses received are complete in all aspects.

\section{Sampling}

A random sampling technique is used by for selecting a sample of 100 consumers of Lucknow city in Uttar Pradesh. Data is collected through a structured questionnaire designed using Likert scale.

The major parameters of customer perception towards CRM practices used in the study includes:

Reliability: which is further divided into sub-parameters like product quality, timely delivery, brand image and past experience.

Customer service: which is further divided into sub-parameters like feedback collection/ complaint resolution, customer care executive behavior, loyalty/membership programs and return/exchange policy.

Product attributes: which is further divided into sub-parameters like variety, availability, packaging and pricing/offers.

Convenience: which is further divided into sub-parameters like operational timings, location, facilities and payment options.

Ambience: which is further divided into sub-parameters like store/website layout, hygiene factors, product display and security/privacy. 
Data analysis tools and techniques

Data collected through the above study is summarized and hypothesis testing is done using two-way ANOVA as a statistical tool.

\section{Hypothesis}

On the basis of the nature of study and the parameters understudy, below mentioned hypothesis is tested on the data collected:

\section{Null hypothesis:}

H0: There is no significant difference in the impact of CRM practices on consumer perception towards organized online and offline retailing

\section{Alternate hypothesis:}

H1: There is a significant difference in the impact of CRM practices on consumer perception towards organized online and offline retailing.

\section{Secondary data}

The secondary data is collected from several journals (national as well as international), government reports, books \& articles, newspapers \& magazines, incorporating ample variety of literature on Indian retail.

\section{DATA COLLECTION AND ANALYSIS}

Table 1: Demographic profiling of collected data

\begin{tabular}{l|l|l|l|l}
\hline Demographic parameter & \multicolumn{3}{|c}{ Value } \\
\hline Gender & Male $=56$ & Female $=44$ & & \\
Age group & Below 25 =28 & $25-35=22$ & $36-45=29$ & Above 45=21 \\
Occupation & Students $=18$ & Housewife =25 & Business owners =28 & Working professionals = 29 \\
Income level & Below 10000=30 & $10000-20000=25$ & $20000-30000=22$ & Above 30000 23 \\
\hline
\end{tabular}

\section{Demographical analysis:}

As from the above table, total data of 100 respondents are collected consisting of $56 \%$ male and $44 \%$ female respondents. Majority of the people participated in the survey were of 36 to 45 years and below 25 years age group i.e., $29 \%$ and $28 \%$ respectively. People who are the main earners and/or spenders like working professionals, business owners and housewives have $82 \%$ participation in the study. People from all income groups participated and help in enriching the survey by providing their responses.

\section{Parameters Analysis:}

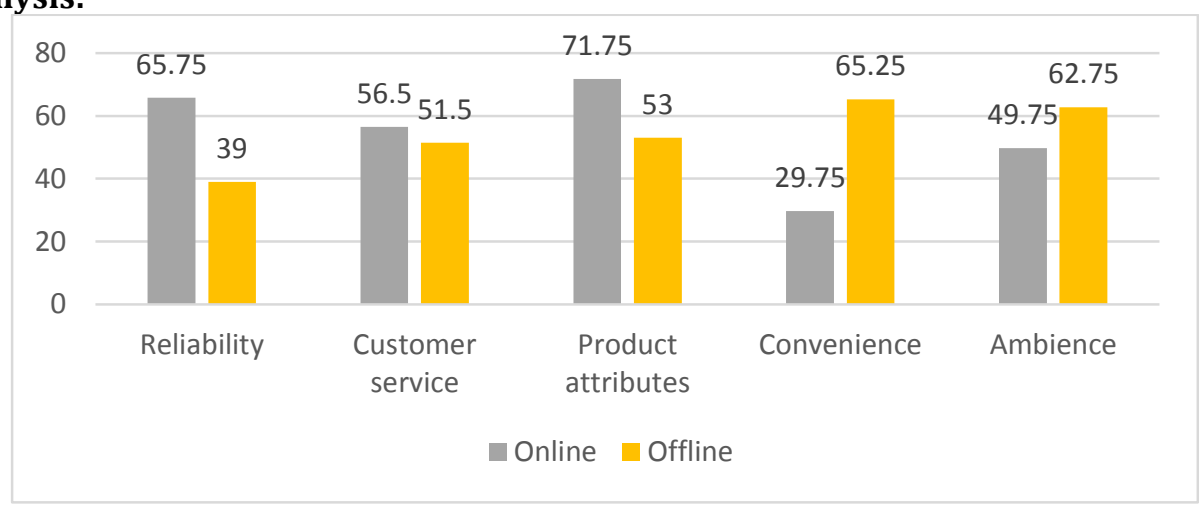

Figure 1: Bar-chart for analysis of selected parameters

Remark: As we can see (refer Figure 1) the total percentage in each parameter is greater than hundred, it is because of the fact that some customers gave importance to both the retail formats considering the parameters as shown above.

On the basis of study and research done we have obtained the above data (refer Figure 1) regarding the importance of various CRM practices parameters as per customers' perspective in Indian retail. we can see that Reliability and Product attributes parameters have high influence in online retail whereas, convenience and Ambience are quite impactful in offline retail. Quite interestingly, it is observed that customer service parameter is more or less hold equal impact on both the formats of retail.

Reliability: Reliability parameter have been given $65.75 \%$ importance as a CRM practices parameter by the customers in Online retail. which implies that product quality, brand image, timely delivery of goods and past 
experiences form a strong basis affecting customer perceptions towards online retail mode but this parameter in not much impactful in offline retail as customers know the location and the offline retailer by face and thus only past experience sub-parameter have some impact in this.

Customer service: Customer service parameter have been given $56.5 \%$ and $51.5 \%$ preference in online and offline retail respectively. This implies that complaint resolution, customer care executive behavior, return or exchange policy hold similar importance to the customer in forming his/her perception towards both retail formats. But, loyalty/membership programs are more preferred sub-parameter in online retail mode as customers availing this facility are given more offers and price discounts in online shopping.

Product attributes: Product attributes parameter have been given $71.75 \%$ importance in online retailing. Which implies that variety and packaging are given more importance in online retail as customers shop online because they want to explore more varieties which are difficult to find in offline mode. Also, packaging is important to online customers, so that their product don't get damaged during transportation. Availability and pricing/offers are more or less customers' preference in both retail formats as customers want its product's availability always with better/affordable prices.

Convenience: Surprisingly, convenience parameter is more impactful in offline retailing as from the above chart it 65.25. Which implies that operational timings, Location and facilities sub-parameters are more impactful in forming customer perception in offline retailing. Whereas, payment options are still important in online retail as customer prefer multiple payment option while purchasing online. Many customers said that they normally pay by cash or UPI in offline stores but prefer multiple options like wallet, UPI, cards, net banking due convenience and associated offers.

Ambience: Ambience is rated 62.75\% important in offline retailing by customers as a parameter forming their perception of CRM practices. Which implies that maintenance \& cleanliness and product display in store is more important sub-parameters in offline retailing as customers prefer visiting and shopping from stores which are clean \& hygienic and all the products are systematically displayed to be found easily. Whereas, safety \& security subparameter holds its importance in online retailing as customers knows the risks of losing personal and payment information while transacting online.

\section{Hypothesis Testing}

We have used two-way ANOVA for analyzing the variation of CRM practices parameters as perceived by the customers in the two retail formats i.e., Online and Offline retailing.

After applying the standard procedure of ANOVA a summary table is prepared which is used to draw further analysis and drawing inferences.

Table 2: Analysis of Variance (ANOVA summary)

\begin{tabular}{lrrr}
\hline Variation component & Variation & Degree of freedom & Estimated variance \\
\hline Columns & 1.6 & 1 & 1.6 \\
Rows & 5158 & 19 & 271.473684 \\
Unexplained & 16030.8 & 19 & 843.726316 \\
Total & 21190.4 & 39 & \\
\hline
\end{tabular}

F statistic $=$ column estimated variance $/$ unexplained estimated variance $=1.6 / 843.726316=0.00189635$

Critical value $=4.381$ (F distribution table)

\section{Inference drawn from above analysis}

Since the F statistic value is less than the critical value of F, thus null hypothesis is accepted. This proved that there is no significant difference in the impact of CRM practices on consumer perception towards organized online and offline retailing. Thus, consumer perception is considerably affected by the CRM practices parameters understudy in both the formats of retailing. Although, some parameters are quite impactful in one format and some in other format.

\section{MAJOR FINDINGS}

i. It is observed that Reliability and Product attributes are major deciding parameters in online retailing.

ii. Convenience and ambience are significant parameters in offline retailing.

iii. It is interesting fact that customer service has equal importance in both the formats of retail, although loyalty/membership factor of customer service is more important for customer's perception in online.

iv. Customers who prefer online mode are more brand conscious as compared to offline retail ones.

v. Due to convenience customers prefer online mode as they have varied payment options.

vi. On the basis of analyzed data and hypothesis tested, it is concluded that selected parameters for CRM practices have considerable impact on customer's perception towards organized retail.

vii. Data analysis also reveal that there is no significant difference in customer perception towards CRM practices in online and offline formats of retail. 


\section{PROPOSED THEORETICAL MODEL FOR STUDYING CUSTOMER PERCEPTION}

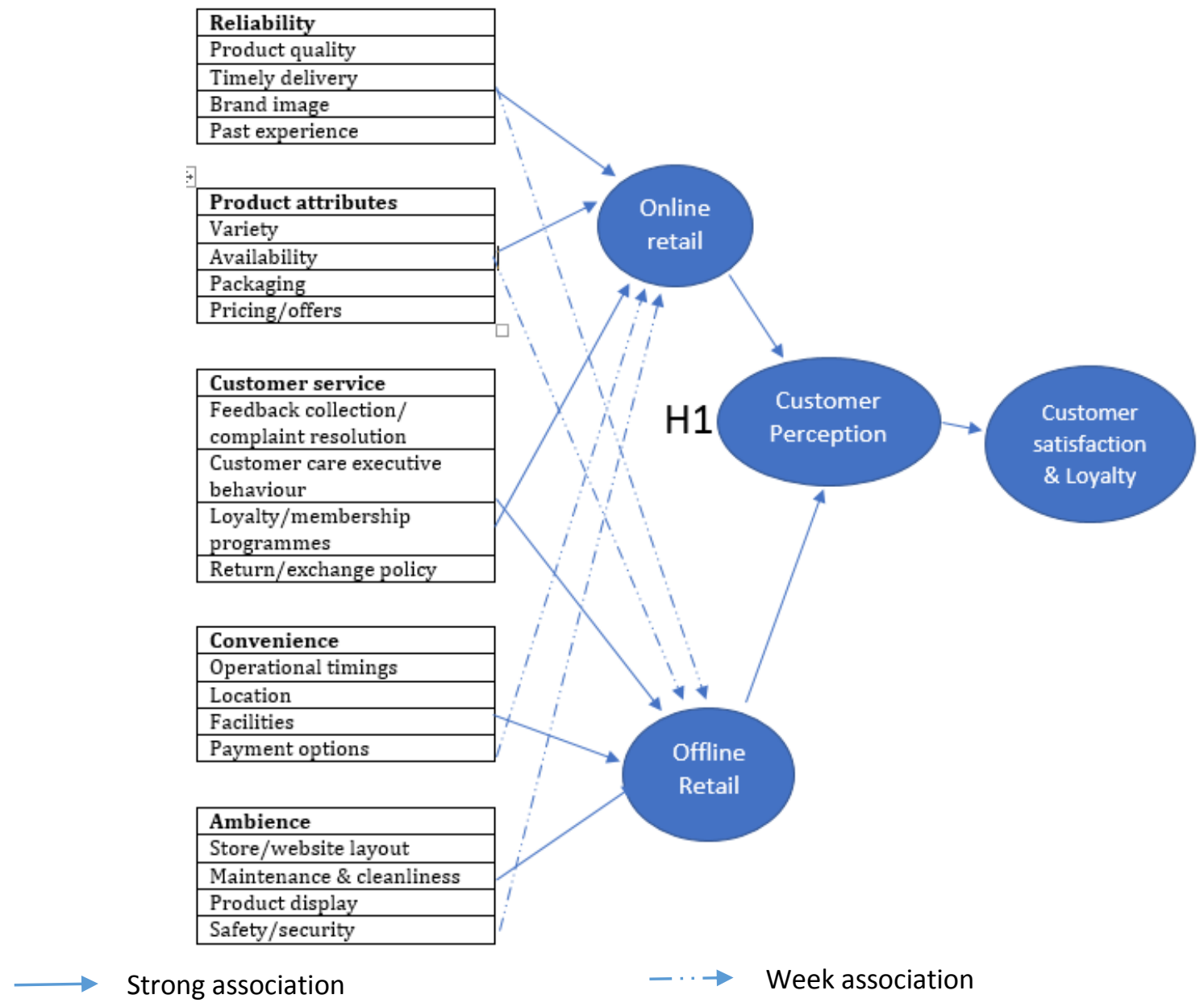

Figure 2: Proposed theoretical model for studying customer perception

The model is based upon the analysis and finding of the study. Following are the details:

1. Reliability and product attributes are having strong association with online form of retailing, in forming customer perception towards CRM practices. Also, these parameters have weak association with offline form of retailing, in forming customer perception.

\section{Reasons:}

- $\quad$ Risk of quality of product and its timely \& fast delivery affects customer's online buying interests.

- Customer's past experiences of online payment issues, delivery due dates and reliable quality of products and services affects his/her loyalty to online retail.

- Customer can directly check the quality of product, self-pick of products of desired brand lowers its significance in offline retailing

2. Convenience and Ambience are having strong association with offline form of retailing, in forming customer perception towards CRM practices. Also, these parameters have weak association with online form of retailing, in forming customer perception.

\section{Reasons:}

- $\quad$ Offline stores are operational for limited time in a day/week.

- Nearby customers pay more visits to offline stores to save time \& cost.

- Offline stores offer facilities like, rest rooms, drinking water etc. to customers.

- Some offline retailers offer credit facilities to their regular customers.

- Online retailers are not bound much to these sub-parameters. 
3. Customer service is having good association with both the forms i.e., online \& offline retailing, in forming customer perception towards CRM practices.

\section{Reasons:}

- Customers appreciates retailer's feedback/complaint resolution initiatives.

- Face to face or online customer care executive behavior forms a perception about the retailer.

- Customers prefer shopping at retailers where they can exchange or return products.

4. Customer perception formed as per the interpretation of these parameters by the customer leads to customer satisfaction and affects their loyalty towards retailing.

\section{CONCLUSION}

This research concludes that CRM practices are important in shaping customer perception towards retail. The significant factors analyzed in this study shows some encouraging and astonishing results, which may be helpful in refining the CRM strategies to build customer loyalty in retail sector. In Indian retail scenario parameters such as reliability, customer service, product attributes, convenience and ambience certainly affect the customer perceptions and loyalty. Businesses are thrusting upon improving customer shopping experiences by improving their CRM practices in both online and offline retail. Comparative study between two modes of retail viz., online and offline retail, reveals that reliability and product attributes are major deciding parameters of customer perception in online retailing. Whereas, convenience and ambience are significantly important criteria for forming customer perceptions towards offline retailing. This study also unveils the prime importance of customer service in both the retail formats as a deciding parameter for customer delight. An interesting fact observed that all brand conscious and price sensitive customers prefer online shopping mode.

So, finally it is concluded that there is no significant difference in customer perception towards CRM practices used in both the retail formats, although some parameters are more impactful in online retail and some are more in offline retailing. This can be the area of application for retail sector to work upon the respective parameters considering their mode of business and expertise.

\section{RECOMMENDATIONS}

It is need of the hour that online retail business should focus on effective logistics and supply chain management system to fulfill the customers' expectations of product quality, timely delivery of goods, customer experience, so as to improve the reliability index of the customer. Through effective upstream and downstream supply chain integration, online retailers can ensure that goods of right quality and quantity can be offered to the customers at the right place and price in the desired form.

\section{General:}

i. Better upstream and downstream supply chain integration can reduce cost, improve quality and availability.

ii. Both formats of retailers should act as mediator between the brand and the customer to minimize any communication gap and resolving any issues pertaining to products sold.

\section{Offline:}

i. Offline retailers should tie up with companies working in $\mathrm{O} 2 \mathrm{O}$ (offline to online) area, so as to provide online services to customers without owning any infrastructure/technology for the same.

ii. Offline retailers should increase their operational timings to serve the broader spectrum of customers from different demographics.

iii. Offline retailers should work on mobile shopping vehicle model, as seen in other sectors like banking(atm), dairy etc., to improve the customer convenience by serving them in their localities only.

iv. Mobile shopping vehicle model can tap the customers of semi-urban, rural and remote locations.

\section{Online:}

i. A simple, feature rich and fast loading website/app can improve customer service and raise their conversion rate.

ii. Online retailers should have a loyalty/membership program as this can attract a customer to make a second purchasing in lieu of a reward.

iii. Online retailers should have a strict quality policy for the products they sell on their store as it affects customers experience and re-purchasing behavior. 
iv. Companies should develop a delivery model along with their logistics partners to offer fast, free and frequent deliveries as well as return pickups.

\section{REFERENCES}

Arditto, L., Cambra-Fierro, J. J., Fuentes-Blasco, M., Jaraba, A. O., \& Vázquez-Carrasco, R. (2020). How does customer perception of salespeople influence the relationship? A study in an emerging economy. Journal of Retailing and Consumer Services, 54, 101952.

Banu, M.A.P., and Nilofer, A. (2019) “Consumers' perception towards CRM practices of E -Commerce business in Tiruchirappalli city", A Journal of Composition Theory, 7(9), 1609. http://www.jctjournal.com/gallery/179sep2019.pdf

Dubey, N. K., \& Sangle, P. (2019). Customer perception of CRM implementation in banking context: Scale development and validation. Journal of Advances in Management Research.

Gauri, D. K., Jindal, R. P., Ratchford, B., Fox, E., Bhatnagar, A., Pandey, A., ... \& Howerton, E. (2021). Evolution of retail formats: Past, present, and future. Journal of Retailing, 97(1), 42-61.

Grosso, M., Castaldo, S., \& Grewal, A. (2018). How store attributes impact shoppers' loyalty in emerging countries: An investigation in the Indian retail sector. Journal of Retailing and Consumer Services, 40, 117-124.

Hasan, A. (2018). Impact of store and product attributes on purchase intentions: An analytical study of apparel shoppers in Indian organized retail stores. Vision, 22(1), 32-49.

Indian Brand Equity Foundation (2020). Indian E-commerce industry report. Retrieved from https://www.ibef.org/archives/industry/ecommerce-reports/indian-ecommerce-industry-analysisnovember-2020

Jain, M. K., Dalela, A. K., \& Tiwari, S. K. (2009). Customer Relationship Management in Indian Retail Market. International Journal of Information Technology, 2(2), 493-497.

Pizzi, G., \& Scarpi, D. (2020). Privacy threats with retail technologies: A consumer perspective. Journal of Retailing and Consumer Services, 56, 102160.

Retail, A. (2020). Indian Retail: Certainty Despite Headwinds. Retrieved from Retailers Association of India database. https://rai.net.in/images/insights/RAI-Anarock\%20Retail\%20Report.pdf

Shaon, S. K. I., \& Rahman, H. (2015). A theoretical review of CRM effects on customer satisfaction and loyalty. Central European Business Review, 4(1), 23.

Sharma, A.K. \& Parveen, M. (2017). Store ambience and its impact on the impulse buying behaviour of college students in haryana. Elk Asia Pacific Journal of Marketing and Retail Management. 8 (2). ISSN 2349-2317 (Online); DOI: 10.16962/EAPJMRM/issn. 2349-2317/2015. Retrieved from https://www.elkjournals.com/MasterAdmin/ UploadFolder/STORE\%20AMBIENCE\%20AND\%20ITS\%20IMPACT\%200N\%20THE\%20IMPULSE/STORE\%2 OAMBIENCE\%20AND\%20ITS\%20IMPACT\%200N\%20THE\%20IMPULSE.pdf

Sharma, M. and Dubey, N. (2017). "A study of customer relationship management in retail outlets at Bhopal, India", Research Journal of Management Sciences, 6(2), 8-11. http://www.isca.in/IJMS/Archive/v6/i2/2.ISCA-RJMS2016-125.pdf

Singh, S., Mondal, S., Singh, L. B., Sahoo, K. K., \& Das, S. (2020). An empirical evidence study of consumer perception and socioeconomic profiles for digital stores in Vietnam. Sustainability, 12(5), 1716.

Thenmozhi, S., \& Rajan, S. D.A. (2018). Impact of Customer Relationship Management on Customer Satisfaction and Customer Loyalty in Retail Sector. International Journal for Research in Engineering Application \& Management (IJREAM), ISSN: 2454-9150, Special Issue NCSDTM-2018, https://www.ijream.org/papers/NCSDTM201813.pdf

Yuen, E. F., \& Chan, S. S. (2010). The effect of retail service quality and product quality on customer loyalty. Journal of Database Marketing \& Customer Strategy Management, 17(3), 222-240.

Publisher's note: Science Impact Publishers remain neutral with regard to jurisdictional claims in published maps and institutional affiliations.

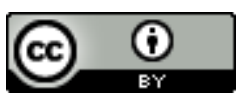

Open Access This article is licensed under a Creative Commons Attribution 4.0 International License, which permits use, sharing, adaptation, distribution and reproduction in any medium or format, as long as you give appropriate credit to the original author(s) and the source, provide a link to the Creative Commons license and indicate if changes were made. The images or other third-party material in this article are included in the article's Creative Commons license, unless indicated otherwise in a credit line to the material. If material is not included in the article's Creative Commons license and your intended use is not permitted by statutory regulation or exceeds the permitted use, you will need to obtain permission directly from the copyright holder. To view a copy of this license, visit https://creativecommons.org/licenses/by/4.0/.

(C) The Author(s) 2021 